2016

\title{
The A. S. Mann (41HE7/41AN201) and M. S. Roberts (41HE8) Sites in the Upper Neches River Basin, Henderson County, Texas
}

Timothy K. Perttula

Heritage Research Center, Stephen F. Austin State University

Waldo Troell

Follow this and additional works at: https://scholarworks.sfasu.edu/ita

Part of the American Material Culture Commons, Archaeological Anthropology Commons, Environmental Studies Commons, Other American Studies Commons, Other Arts and Humanities Commons, Other History of Art, Architecture, and Archaeology Commons, and the United States History Commons

Tell us how this article helped you.

This Article is brought to you for free and open access by the Center for Regional Heritage Research at SFA ScholarWorks. It has been accepted for inclusion in Index of Texas Archaeology: Open Access Gray Literature from the Lone Star State by an authorized editor of SFA ScholarWorks. For more information, please contact cdsscholarworks@sfasu.edu. 


\section{The A. S. Mann (41HE7/41AN201) and M. S. Roberts (41HE8) Sites in the Upper}

Neches River Basin, Henderson County, Texas

\section{Creative Commons License}

\section{(c) (1) \&}

This work is licensed under a Creative Commons Attribution-NonCommercial 4.0 International License 


\title{
The A. S. Mann (41HE7/41AN201) and M. S. Roberts (41HE8) Sites in the Upper Neches River Basin, Henderson County, Texas
}

\author{
Timothy K. Perttula, with contributions by Waldo Troell
}

\section{INTRODUCTION}

The upper Neches River basin in East Texas has been the scene of archaeological research since the early 1900s (see Perttula et al. 2011:19-34), with a particular focus on the post-A.D. 1000 archaeological record of the Caddo peoples in the region. The A. S. Mann (41HE7) and M. S. Roberts (41HE8) sites are ancestral Caddo sites located in the modern-day Pineywoods (Figure 1) that were investigated by University of Texas (UT) archaeologists in the 1930s. I want to thank Waldo Troell for bringing these sites to my attention.

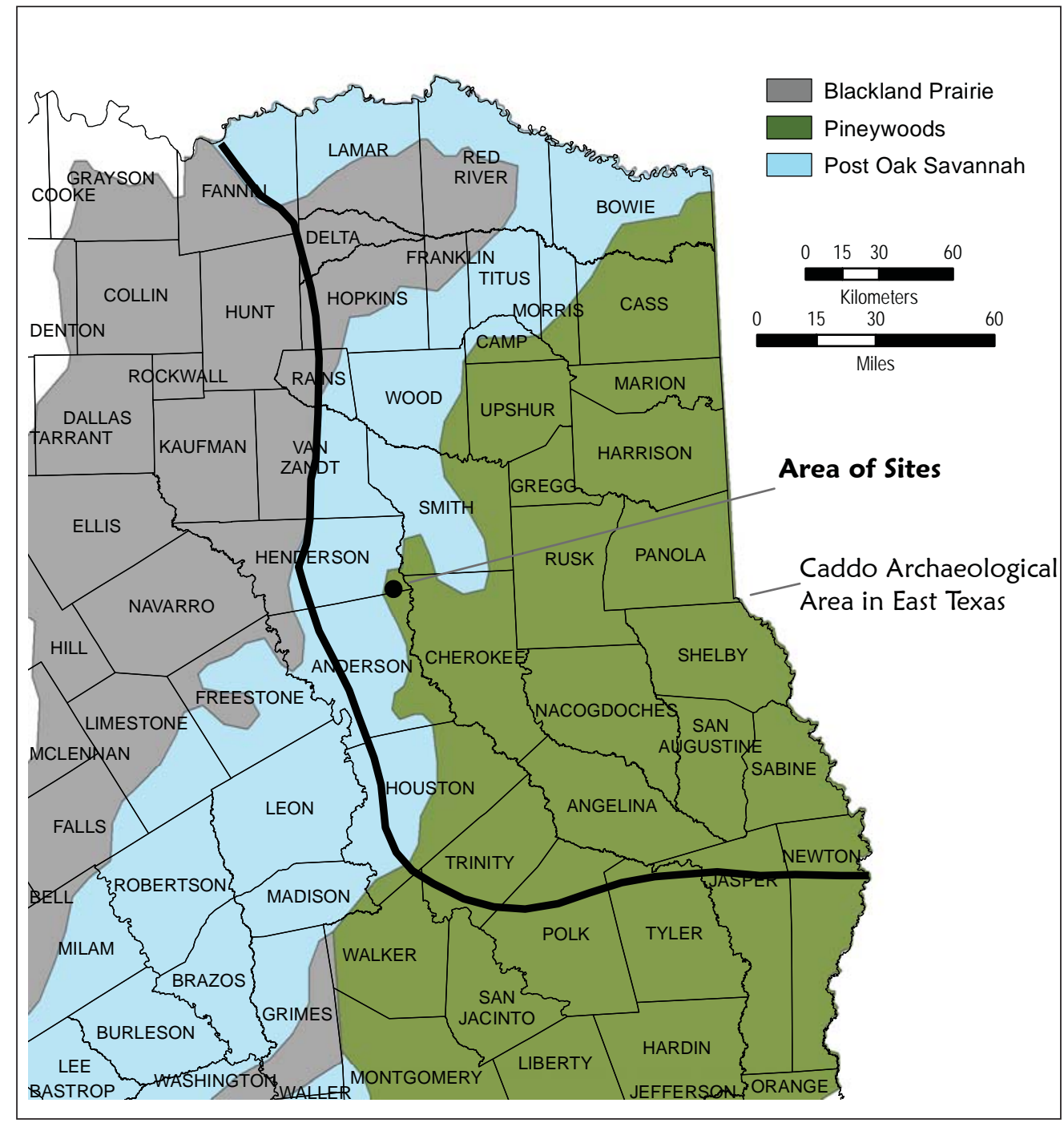

Figure 1. The location of the A. S. Mann (41HE7) and M. S. Roberts (41HE8) sites in East Texas. 


\section{S. Mann Site (41HE7/41AN201)}

The A. S. Mann site is the location of a small ancestral Caddo cemetery in the Caddo Creek valley in the upper Neches River basin, about $6.5 \mathrm{~km}$ west of the small town of Frankston, Texas (see Figure 1, see also Troell's discussion below). The cemetery was found by a Mr. John Riley in June or July, 1935, when he noted a ceramic bottle eroding from a gully that crossed an uncultivated field.

In October 1935, UT archaeologists followed up on this find and excavated a number of areas around the bottle (Woolsey 1935). In this work, they identified two Caddo burials (AF-1 and AF-2); the bottle found earlier by Riley was one of the funerary offerings in Burial AF-1 (Figure 2).

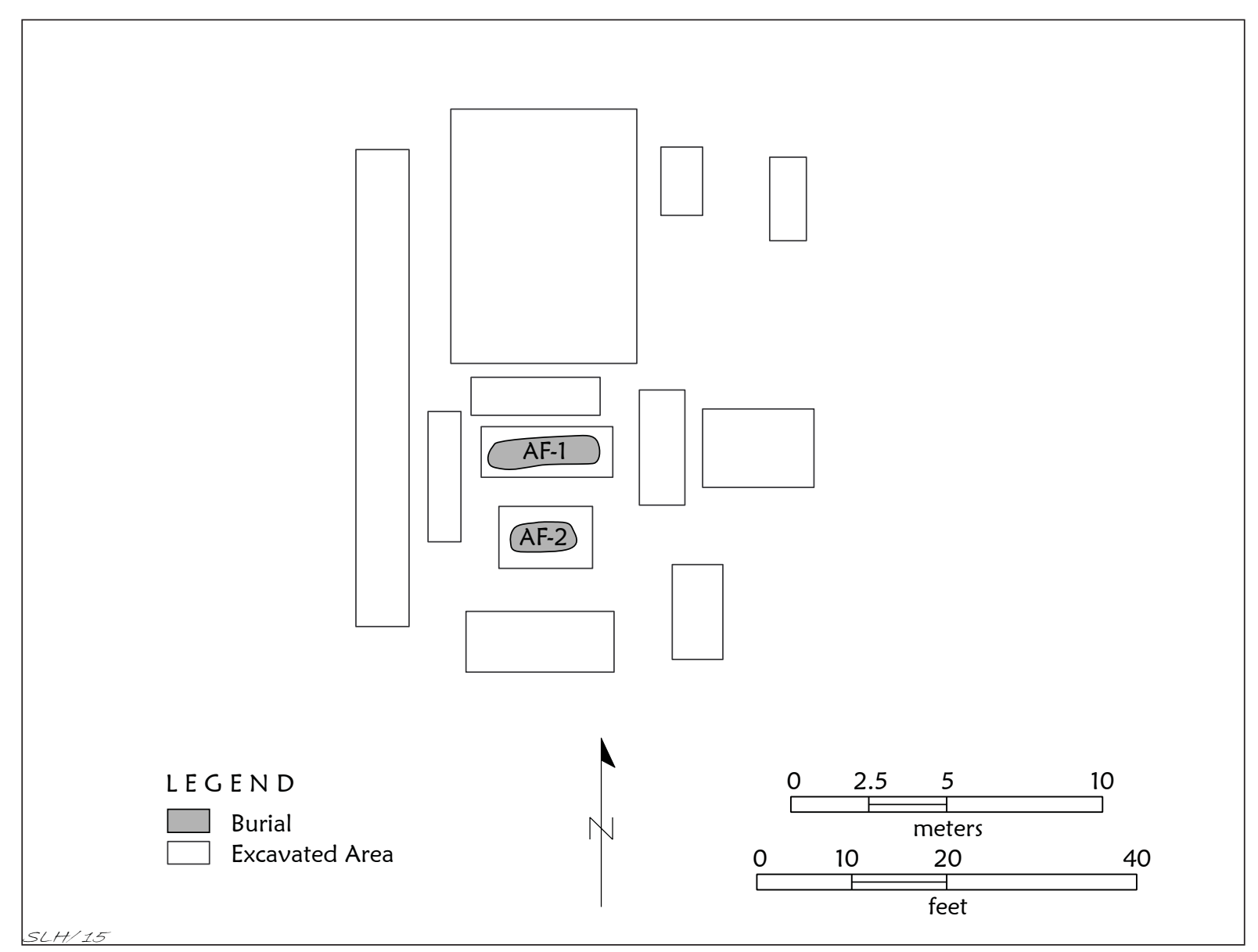

Figure 2. Excavations at the A. S. Mann site.

Burial AF-1 was that of an adult laid out in an extended supine position, with the head at the eastern end of the grave and facing west. The grave was $208 \times 56 \mathrm{~cm}$ in length and width, and $56 \mathrm{~cm}$ in depth. Eight ceramic vessels were placed in the grave, primarily around the head and the upper body (Figure 3), as funerary offerings.

Remnants of a second burial-AF-2 - were found ca. $2.7 \mathrm{~m}$ south of Burial AF-1 (see Figure 2). It had been almost completely disturbed by plowing, and all that remained were pieces of a right femur and the base of a ceramic bottle (Woolsey 1935). The grave was $122 \times 41 \mathrm{~cm}$ in length and width, and only ca. 24 $\mathrm{cm}$ in depth; the size of the grave suggests that Burial AF-2 was that of a child or adolescent. 


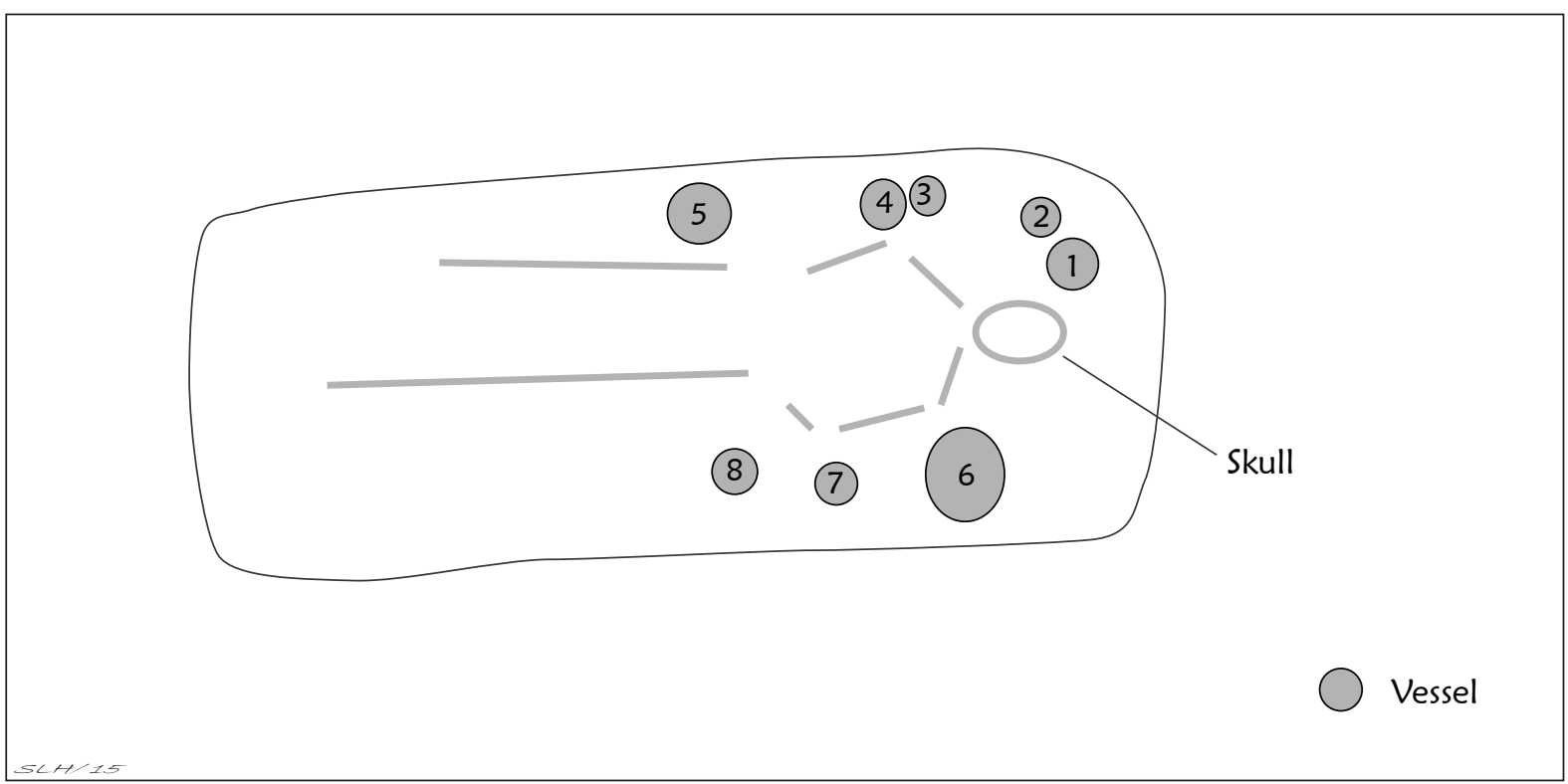

Figure 3. Burial AF-1 at the A. S. Mann site.

\section{Ceramic Vessels from Burial AF-1}

The eight vessels from Burial AF-1 at the A. S. Mann site include one bottle, one jar, an olla fragment, three carinated bowls, a small beaker, and an effigy bowl (with the effigy head missing). The decorative styles on several of the vessels indicate that the burial dates to some part of the Late Caddo period Frankston phase (ca. A.D. 1400-1650).

SITE NAME OR SITE NUMBER: A. S. Mann (41HE7)

VESSEL NO.: Burial AF-1, Vessel 1 (357-624)

VESSEL FORM: Bottle with a short neck and a cylindrical body

NON-PLASTICS AND PASTE: grog

RIM AND LIP FORM: Direct rim and a flat lip

CORE COLOR: $\mathrm{G}$ (fired in a reducing environment and cooled in the open air)

INTERIOR SURFACE COLOR: dark grayish-brown

EXTERIOR SURFACE COLOR: light yellowish-brown; fire clouds on the rim, body, and base

WALL THICKNESS (IN MM): rim, $6.3 \mathrm{~mm}$

INTERIOR SURFACE TREATMENT: none

EXTERIOR SURFACE TREATMENT: smoothed

HEIGHT (IN CM): 22.9 
ORIFICE DIAMETER (IN CM): 5.0

DIAMETER AT BOTTOM OF RIM OR NECK (IN CM): 5.0; $12.9 \mathrm{~cm}$ maximum body diameter

BASE DIAMETER (IN CM) AND SHAPE OF BASE: 8.8; circular and flat

ESTIMATED VOLUME (IN LITERS): 0.78

DECORATION (INCLUDING MOTIF AND ELEMENTS WHEN APPARENT): The vessel body is divided into four panels by sets of three or four closely-spaced vertical engraved lines (Figure 4). Two of the panels have two or three large hatched pendant triangles along the vertical axis and two upper or lower hatched pendant triangles on the horizontal axis of the panels. The other two panels have sets of semi-circles on the vertical axis, and these semi-circles have either two or three large hatched pendant triangles. There are also single upper and lower hatched pendant triangles in these panels, as well as one stand-alone hatched triangle in the lower left corner of the panels.

PIGMENT USE AND LOCATION ON VESSEL: none

TYPE AND VARIETY (IF KNOWN): Poynor Engraved, var. unspecified

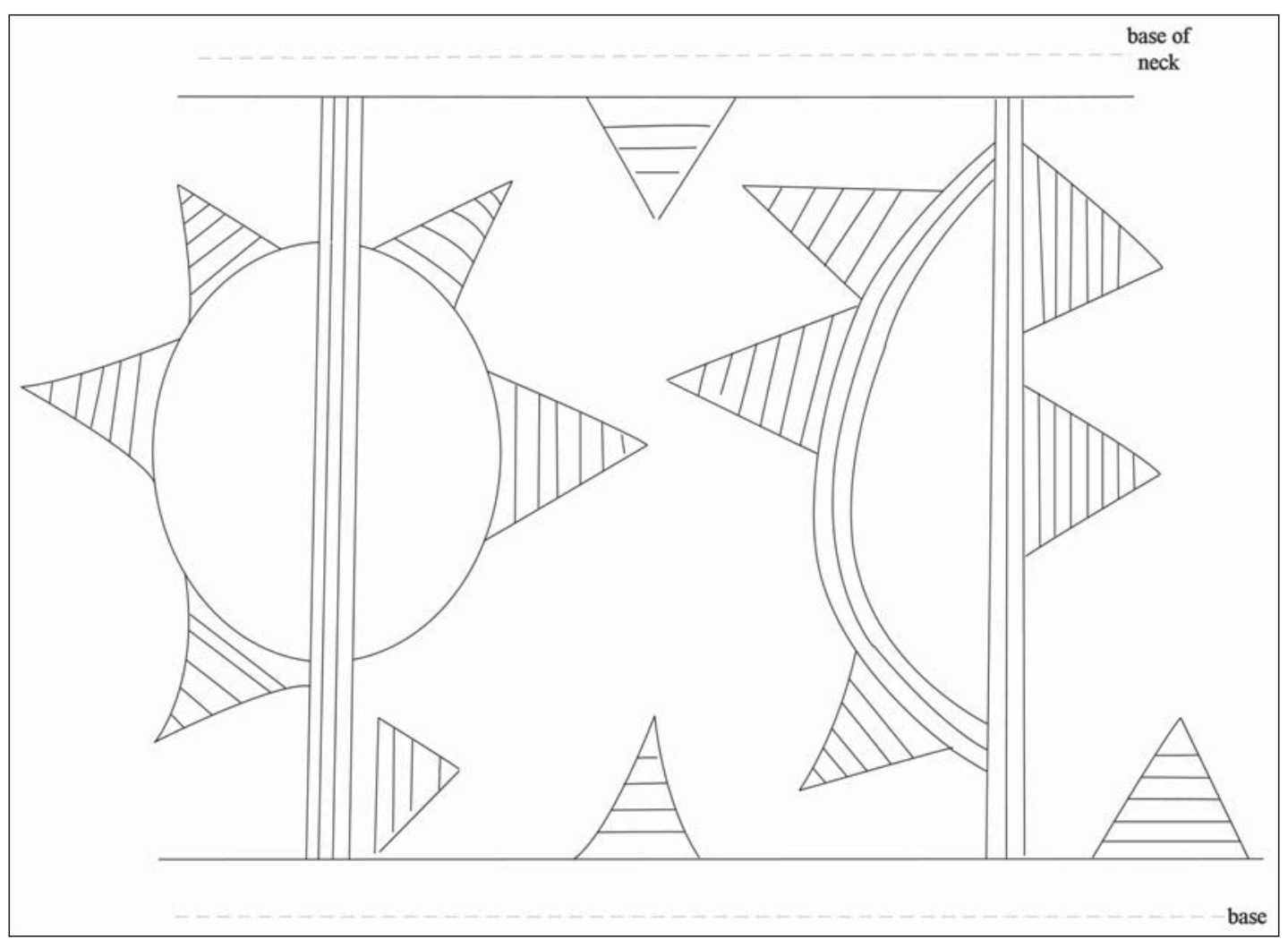

Figure 4. Decorative elements on Poynor Engraved, var. unspecified bottle (Vessel 1, Burial AF-1) from the A. S. Mann site. 
SITE NAME OR SITE NUMBER: A. S. Mann (41HE7)

VESSEL NO.: Burial AF-1, Vessel 2 (357-625)

VESSEL FORM: Jar with two opposed strap handles. The handles extend from the lip to the base of the rim, and are $37-39 \mathrm{~mm}$ in length and $23 \mathrm{~mm}$ in width.

NON-PLASTICS AND PASTE: grog and bone

RIM AND LIP FORM: Everted rim and rounded lip

CORE COLOR: $\mathrm{G}$ (fired in a reducing environment and cooled in the open air)

INTERIOR SURFACE COLOR: dark grayish-brown

EXTERIOR SURFACE COLOR: reddish-brown; fire clouds on the rim, body, and base

WALL THICKNESS (IN MM): rim, 6.4 mm

INTERIOR SURFACE TREATMENT: none

EXTERIOR SURFACE TREATMENT: none

HEIGHT (IN CM): 12.9

ORIFICE DIAMETER (IN CM): 11.3

DIAMETER AT BOTTOM OF RIM OR NECK (IN CM): 10.8

BASE DIAMETER (IN CM) AND SHAPE OF BASE: 6.1; circular and flat

ESTIMATED VOLUME (IN LITERS): 0.87

DECORATION (INCLUDING MOTIF AND ELEMENTS WHEN APPARENT): There are eight horizontal incised lines on the upper part of the vessel, seven on the rim, and the eighth line on the vessel body, and below the attached strap handles. The strap handles are decorated with either two or three vertical pinched ridges.

PIGMENT USE AND LOCATION ON VESSEL: none

TYPE AND VARIETY (IF KNOWN): Unidentified utility ware

SITE NAME OR SITE NUMBER: A. S. Mann (41HE7)

VESSEL NO.: Burial AF-1, Vessel 3 (357-626)

VESSEL FORM: Carinated bowl

NON-PLASTICS AND PASTE: grog

RIM AND LIP FORM: Inverted rim and rounded lip

CORE COLOR: B (fired and cooled in a reducing or low oxygen environment) 
INTERIOR SURFACE COLOR: dark grayish-brown EXTERIOR SURFACE COLOR: dark grayish-brown; fire clouds on the rim and body

WALL THICKNESS (IN MM): rim, 6.7 mm

INTERIOR SURFACE TREATMENT: smoothed

EXTERIOR SURFACE TREATMENT: burnished

HEIGHT (IN CM): 6.0

ORIFICE DIAMETER (IN CM): 12.7

DIAMETER AT BOTTOM OF RIM OR NECK (IN CM): 14.7

BASE DIAMETER (IN CM) AND SHAPE OF BASE: 8.0; circular and flat

ESTIMATED VOLUME (IN LITERS): 0.46

DECORATION (INCLUDING MOTIF AND ELEMENTS WHEN APPARENT): Plain

PIGMENT USE AND LOCATION ON VESSEL: none

TYPE AND VARIETY (IF KNOWN): SITE NAME OR SITE NUMBER: Unidentified plain ware

SITE NAME OR SITE NUMBER: A. S. Mann (41HE7)

VESSEL NO.: Burial AF-1, Vessel 4 (357-627)

VESSEL FORM: Olla with short neck

NON-PLASTICS AND PASTE: grog

RIM AND LIP FORM: N/A

CORE COLOR: F (fired in a reducing environment and cooled in the open air)

INTERIOR SURFACE COLOR: reddish-brown

EXTERIOR SURFACE COLOR: reddish-brown

WALL THICKNESS (IN MM): body, $5.6 \mathrm{~mm}$

INTERIOR SURFACE TREATMENT: none

EXTERIOR SURFACE TREATMENT: smoothed

HEIGHT (IN CM): N/A

ORIFICE DIAMETER (IN CM): N/A 
DIAMETER AT BOTTOM OF RIM OR NECK (IN CM): N/A

BASE DIAMETER (IN CM) AND SHAPE OF BASE: N/A

ESTIMATED VOLUME (IN LITERS): N/A

DECORATION (INCLUDING MOTIF AND ELEMENTS WHEN APPARENT): This vessel fragment has seven rows of fingernail punctations on the upper body. The top four rows are angled from right to left, while the bottom three rows are angled from left to right.

PIGMENT USE AND LOCATION ON VESSEL: none

TYPE AND VARIETY (IF KNOWN): Unidentified utility ware

SITE NAME OR SITE NUMBER: A. S. Mann (41HE7)

VESSEL NO.: Burial AF-1, Vessel 5 (357-628)

VESSEL FORM: Carinated bowl

NON-PLASTICS AND PASTE: grog

RIM AND LIP FORM: Direct rim and rounded lip

CORE COLOR: $\mathrm{G}$ (fired in a reducing environment and cooled in the open air)

INTERIOR SURFACE COLOR: grayish-brown; fire clouds on the base

EXTERIOR SURFACE COLOR: reddish-brown; fire clouds on the base

WALL THICKNESS (IN MM): rim, $5.5 \mathrm{~mm}$

INTERIOR SURFACE TREATMENT: none

EXTERIOR SURFACE TREATMENT: smoothed

HEIGHT (IN CM): 8.0

ORIFICE DIAMETER (IN CM): 17.8

DIAMETER AT BOTTOM OF RIM OR NECK (IN CM): 17.4

BASE DIAMETER (IN CM) AND SHAPE OF BASE: 7.9; circular and flat

ESTIMATED VOLUME (IN LITERS): 0.89

DECORATION (INCLUDING MOTIF AND ELEMENTS WHEN APPARENT): Plain

PIGMENT USE AND LOCATION ON VESSEL: none

TYPE AND VARIETY (IF KNOWN): SITE NAME OR SITE NUMBER: Unidentified plain ware 
SITE NAME OR SITE NUMBER: A. S. Mann (41HE7)

VESSEL NO.: Burial AF-1, Vessel 6 (357-629)

VESSEL FORM: Carinated bowl

NON-PLASTICS AND PASTE: grog

RIM AND LIP FORM: Inverted rim and rounded lip

CORE COLOR: G (fired in a reducing environment and cooled in the open air)

INTERIOR SURFACE COLOR: grayish-brown

EXTERIOR SURFACE COLOR: yellowish-brown; fire clouds on the rim and body

WALL THICKNESS (IN MM): rim, $5.3 \mathrm{~mm}$

INTERIOR SURFACE TREATMENT: smoothed

EXTERIOR SURFACE TREATMENT: burnished

HEIGHT (IN CM): 10.0

ORIFICE DIAMETER (IN CM): 15.0

DIAMETER AT BOTTOM OF RIM OR NECK (IN CM): 16.9

BASE DIAMETER (IN CM) AND SHAPE OF BASE: 7.2; circular and flat

ESTIMATED VOLUME (IN LITERS): 0.90

DECORATION (INCLUDING MOTIF AND ELEMENTS WHEN APPARENT): The rim has a panel defined by single horizontal engraved lines under the vessel lip and just above the vessel carination. The panel has three repeating sets of large ovals (marked by two semi-circular lines on either side of the oval) and a central hooked arm element as seen in Var. N and Var. P of Poynor Engraved (Perttula 2011:Figure 6-65). Both varieties are considered regionally distinctive upper Neches River basin varieties of Poynor Engraved. Dividing each of the ovals and hooked arm elements are engraved brackets with upper and lower negative ovals and surrounding curvilinear lines. Both Variety N and P occur in ca. A.D. 1480-1650 contexts in Frankston phase burial features (Perttula 2011:Table 6-37).

PIGMENT USE AND LOCATION ON VESSEL: red pigment in engraved lines

TYPE AND VARIETY (IF KNOWN): Poynor Engraved, var. unspecified

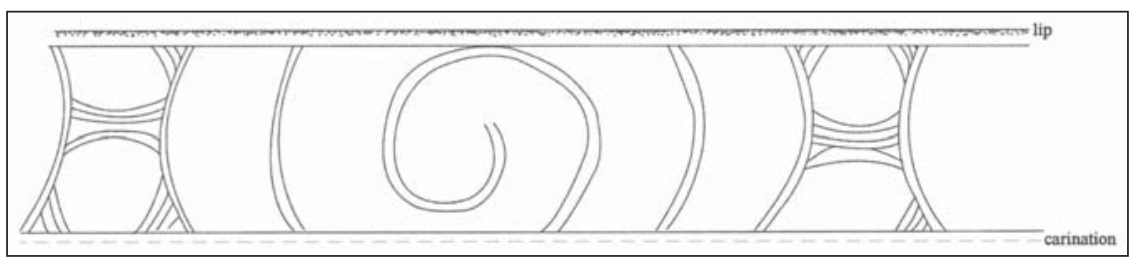

Figure 5. Decorative elements on Poynor Engraved, var. unspecified carinated bowl (Vessel 6, Burial AF-1) from the A. S. Mann site. 
SITE NAME OR SITE NUMBER: A. S. Mann (41HE7)

VESSEL NO.: Burial AF-1, Vessel 7 (357-630)

VESSEL FORM: Beaker

NON-PLASTICS AND PASTE: grog and bone

RIM AND LIP FORM: Everted rim and flat lip

CORE COLOR: F (fired in a reducing environment and cooled in the open air)

INTERIOR SURFACE COLOR: yellowish-brown

EXTERIOR SURFACE COLOR: yellowish-brown; fire clouds on the body and base

WALL THICKNESS

(IN MM): rim, $4.5 \mathrm{~mm}$

INTERIOR SURFACE

TREATMENT: none

EXTERIOR SURFACE

TREATMENT: smoothed

HEIGHT (IN CM): 10.4

ORIFICE DIAMETER

(IN CM): 5.9

DIAMETER AT BOTTOM OF

RIM OR NECK (IN CM): 5.8

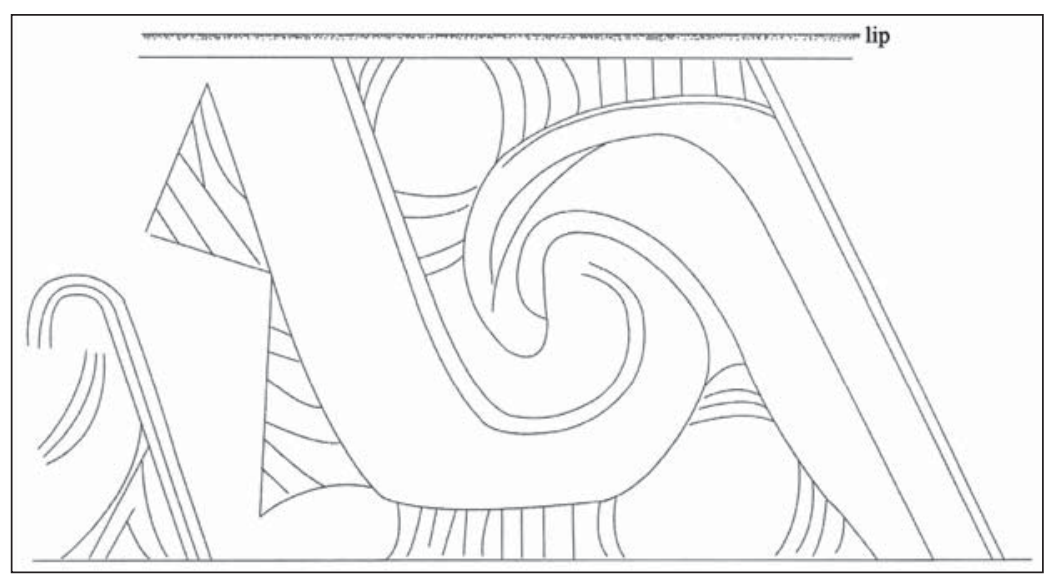

Figure 6. Decorative elements on Poynor Engraved, var. unspecified beaker (Burial AF-1, Vessel 7) from the A. S. Mann site.

BASE DIAMETER (IN CM)

AND SHAPE OF BASE: 5.3;

circular and flat

ESTIMATED VOLUME (IN LITERS): 0.36

DECORATION (INCLUDING MOTIF AND ELEMENTS WHEN APPARENT): The beaker has single upper and lower horizontal engraved lines as well as an engraved motif that is repeated three times around the vessel (Figure 6). The motif consists of a slanting scroll that ends in a hooked arm element as well as negative oval elements and short vertical lines in upper and lower scroll elements. There also are large hatched pendant triangles on a curvilinear line adjacent to the slanting scroll as well as two closely-spaced diagonal engraved lines that divide the scroll motifs from each other.

PIGMENT USE AND LOCATION ON VESSEL: red pigment in engraved lines

TYPE AND VARIETY (IF KNOWN): SITE NAME OR SITE NUMBER: Poynor Engraved, var. unspecified 
SITE NAME OR SITE NUMBER: A. S. Mann site (41HE7)

VESSEL NO.: Burial AF-1, Vessel 8 (325-631)

VESSEL FORM: Effigy bowl with tab tail ( $23 \times 29 \mathrm{~mm}$ in length and width) at one end of the vessel; the effigy head is missing and has been broken off at the other end of the vessel.

NON-PLASTICS AND PASTE: grog and bone

RIM AND LIP FORM: Direct rim and rounded lip

CORE COLOR: A (fired and cooled in an oxidizing or high oxygen environment)

INTERIOR SURFACE COLOR: reddish-brown

EXTERIOR SURFACE COLOR: reddish-brown; fire clouds on the rim, body, and base

WALL THICKNESS (IN MM): rim, $6.0 \mathrm{~mm}$; base, $7.5 \mathrm{~mm}$

INTERIOR SURFACE TREATMENT: none

EXTERIOR SURFACE TREATMENT: none

HEIGHT (IN CM): 3.5

ORIFICE DIAMETER (IN CM): 7.8

DIAMETER AT BOTTOM OF RIM OR NECK (IN CM): N/A

BASE DIAMETER (IN CM) AND SHAPE OF BASE: 3.4; circular and flat

ESTIMATED VOLUME (IN LITERS): 0.11

DECORATION (INCLUDING MOTIF AND ELEMENTS WHEN APPARENT): The bowl has three horizontal engraved lines on the upper part of the vessel.

PIGMENT USE AND LOCATION ON VESSEL: none

TYPE AND VARIETY (IF KNOWN): Hood Engraved, var. unspecified

\section{Locating the A.S. Mann site in 2014, Waldo Troell}

The exact location of the A. S. Mann site had been lost since the 1935 work by UT archaeologists. The rediscovery of the lost A. S. Mann site (41HE7) came about while preparing the background information for a Texas Department of Transportation archaeological survey. I noticed on the 1932 Plans of Proposed State Highway Improvement for Highway 40 for Anderson and Henderson counties (CSJ 0198-03-006 and 0198-02-004) that one of the parcels was noted as the A. S. Mann property in Anderson County. This name matched the owner of the property listed on the site form for 41HE7 but the exact location of the site was unknown; it had been assigned to an area in Henderson County near the county line with Anderson County.

Following the archaeological survey performed by Versa Inc., consultant archaeologists Christopher Goodmaster and Andrew Parkyn notified me that they had indeed found an unrecorded site on the old Mann 
property. A further review of the above mentioned 1932 Planning document and the 1936 State of Texas Highway Department County maps for Anderson and Henderson counties revealed that the road from Athens to Jacksonville was called Highway 40, and before 1933 consisted of a winding road that followed property boundaries north of the current highway U.S. 175. A new linear Highway 40 was constructed south of the old Highway 40 between 1932 and 1933. The old highway 40 was converted into a series of county roads. By 1936 the new Highway 40 was renamed U.S. 175.

With the help of TARL staff members Jonathan Jarvis and Jean Hughes, I located the original report by J. E. Pearce and A. M. Woolsey (1935) and the site maps. This information indicated three important points about the site location, one being that Pearce and Woolsey believed (correctly) that the A.S. Mann Farm was in Anderson County. The second point was that the field work was done in 1935, which meant that Woolsey was referring to the new Highway 40 that later became U.S. 175. The third point was that Woolsey did not take precise measurements but guessed at the distance of landmarks and features. A number of the measurements were changed several times after returning from the field, then rounded up for the report. The highway location and name changes coupled with the imprecise site location measurements caused the site to be later incorrectly plotted in Henderson County. Since Pearce and his UT staff recorded multiple sites on Highway 40, one has to take into account the year the field work was performed to determine if one needs to measure from the current highway U.S. 175 or the old location of Highway 40 to locate these old sites.

\section{S. Roberts Site (41HE8)}

This ancestral Caddo site was reported to Dr. J. E. Pearce of The University of Texas (UT) in September 1931 by Jeff D. Reagan of Palestine, Texas. In October 1931, a UT crew investigated the site, which had an earthen mound and an associated settlement (Pearce and Jackson 1931).

The site is on an alluvial terrace (420 ft. amsl) on the north side of Caddo Creek, an eastward-flowing tributary to the Neches River, about $1.6 \mathrm{~km}$ west of Poynor, Texas (see Figure 1). The M. S. Roberts site has a single earthen mound about $24 \times 20 \mathrm{~m}$ in length and width, and it was estimated to stand $1.7 \mathrm{~m}$ in height. A likely borrow pit depression was noted just to the west of the mound. Artifacts were noted and collected by Pearce and Jackson (1931) from the plowed surface of the mound and surrounding Caddo habitation areas on the alluvial terrace.

The UT work consisted of the excavation of an unknown number of trenches into the earthen mound. The trenches disclosed an undifferentiated mound fill from $0-114 \mathrm{~cm}$ bs that had ash, ceramic sherds, and animal bones. The mound fill rested atop a clay floor $(114-122 \mathrm{~cm} \mathrm{bs})$ from a burned Caddo structure, and this clay floor was placed atop the first mound fill zone, a yellow sand $(122-146 \mathrm{~cm} \mathrm{bs})$ that also had unspecified associated midden materials. These first mound deposits were constructed on top of the natural ground surface, a brown sandy loam A- and E-horizon that was uncovered between 146-196+ $\mathrm{cm}$ bs. The mound at the M. S. Roberts site was undoubtedly built to cover an important Caddo structure, most likely a structure used for political and religious ceremonies or used as the residence of an important and elite member of the local Caddo community.

\section{Ceramic Sherds}

There are 419 sherds from ceramic vessels in the Texas Archeological Research Laboratory (TARL) collections from the M. S. Roberts site (Table 1). This includes 253 plain sherds and 166 decorated sherds; the plain to decorated sherd ratio is 1.52. About 83 percent of the decorated sherds (and 52 percent of all the rim sherds from the assemblage) are from utility ware vessels, namely vessels that were decorated with wet paste designs (i.e., incised, punctated, brushed, etc.). That 31 percent of the rims in the assemblage are from plain wares (Table 1) suggests that plain wares (jars and bowls) were in relatively common use at the site, as were utility wares (primarily jars). 
Table 1. Ceramic sherds from the M. S. Roberts Site (41 HE8).

\begin{tabular}{lllll}
\hline Ware & Rim & Body & Base & N \\
\hline Plain & 9 & 227 & 17 & 253 \\
Utility & 15 & 123 & - & 138 \\
Fine & 5 & 23 & - & 28 \\
\hline Totals & 29 & 373 & 17 & 419 \\
\hline
\end{tabular}

Among the plain sherds is the rim to an effigy bowl as well as a broken ceramic spindle whorl. The drilled hole in the spindle whorl is $9.6 \mathrm{~mm}$ in diameter.

Based on the decorated sherds from the site, the sherds from the M. S. Roberts site are from vessels tempered with either grog (i.e., crushed sherds) or burned bone (Table 2). About 86 percent of the sherds are from grog-tempered vessels; more than 96 percent of the fine ware sherds are from grog-tempered vessels, compared to 84 percent of the utility wares. Overall, 14 percent of the sherds are from bone-tempered vessels: 15.9 percent of the utility wares but only 3.6 percent of the fine wares.

Table 2. Temper in the utility ware and fine ware sherds from the M. S. Roberts site (41HE8).

\begin{tabular}{llll}
\hline Ware & grog temper & bone temper & $\mathrm{N}$ \\
\hline Utility & 116 & 22 & 138 \\
Fine & 27 & 1 & 28 \\
\hline Totals & 143 & 23 & 166 \\
\hline
\end{tabular}

The principal decorative methods represented in the utility ware sherds from the M. S. Roberts site have incised ( $\mathrm{n}=52,37.7$ percent), punctated ( $\mathrm{n}=39,28.3$ percent), and brushed ( $\mathrm{n}=28,20.3$ percent) decorative elements (Table 3); another 4.3 percent of the sherds have brushed-incised or brushed-punctated decorative elements. Sixty percent of the utility ware rim sherds have incised decorative elements.

Table 3. Decorative elements on utility ware sherds from the M. S. Roberts site.

\begin{tabular}{|c|c|c|c|}
\hline $\begin{array}{l}\text { Decorative method/ } \\
\text { Decorative element }\end{array}$ & Rim & Body & $\mathrm{N}$ \\
\hline \multicolumn{4}{|l|}{ Appliqued } \\
\hline curvilinear appliqued ridges & - & 1 & 1 \\
\hline parallel appliqued fillets & $1^{*}$ & - & 1 \\
\hline straight appliqued fillet and appliqued node & - & 1 & 1 \\
\hline \multicolumn{4}{|l|}{ Brushed } \\
\hline diagonal brushing marks & - & 1 & 1 \\
\hline horizontal brushing marks & 1 & - & 1 \\
\hline opposed brushing marks & - & 4 & 4 \\
\hline overlapping brushing marks & - & 5 & 5 \\
\hline parallel brushing marks & - & 17 & 17 \\
\hline \multicolumn{4}{|l|}{ Brushed-Incised } \\
\hline parallel brushing marks and incised lines & - & 3 & 3 \\
\hline parallel brushing marks and overlying opposed & - & 1 & 1 \\
\hline
\end{tabular}


Table 3. Decorative elements on utility ware sherds from the M. S. Roberts site, cont.

\begin{tabular}{|c|c|c|c|}
\hline $\begin{array}{l}\text { Decorative method/ } \\
\text { Decorative element }\end{array}$ & $\operatorname{Rim}$ & Body & $\mathrm{N}$ \\
\hline $\begin{array}{l}\text { parallel brushing marks and overlying parallel } \\
\text { incised lines }\end{array}$ & - & 1 & 1 \\
\hline \multicolumn{4}{|l|}{ Brushed-Punctated } \\
\hline $\begin{array}{l}\text { parallel brushing marks and fingernail punctated } \\
\text { row through the brushing }\end{array}$ & - & 1 & 1 \\
\hline \multicolumn{4}{|l|}{ Incised } \\
\hline cross-hatched line & 1 & 4 & 5 \\
\hline curvilinear lines & - & 1 & 1 \\
\hline diagonal lines & 4 & 1 & 5 \\
\hline diagonal opposed lines & 1 & 13 & 14 \\
\hline hatched zones & - & 1 & 1 \\
\hline horizontal lines & 1 & - & 1 \\
\hline horizontal and diagonal lines & - & 5 & 5 \\
\hline $\begin{array}{l}\text { horizontal and diagonal lines and hatched } \\
\text { pendant triangles }\end{array}$ & 1 & - & 1 \\
\hline horizontal, curvilinear, and vertical lines & 1 & - & 1 \\
\hline horizontal line and negative oval el. & - & 1 & 1 \\
\hline parallel lines & - & 16 & 16 \\
\hline straight line & - & 1 & 1 \\
\hline \multicolumn{4}{|l|}{ Incised-Punctated } \\
\hline $\begin{array}{l}\text { curvilinear incised zones filled with tool } \\
\text { punctates }\end{array}$ & - & 1 & 1 \\
\hline $\begin{array}{l}\text { diagonal lines and circular punctated-filled } \\
\text { incised triangle }\end{array}$ & 1 & - & 1 \\
\hline $\begin{array}{l}\text { diagonal incised panels filled with tool } \\
\text { punctates }\end{array}$ & 1 & 1 & 2 \\
\hline $\begin{array}{l}\text { horizontal-vertical-diagonal incised lines [on } \\
\text { lower rim] and fingernail punctated rows } \\
\text { [on body] }\end{array}$ & - & 1 & 1 \\
\hline incised triangles filled with tool punctates & - & 3 & 3 \\
\hline $\begin{array}{l}\text { parallel incised lines with fingernail punctated } \\
\text { rows through the incised lines }\end{array}$ & - & 2 & 2 \\
\hline \multicolumn{4}{|l|}{ Punctated } \\
\hline fingernail punctated rows & - & 23 & 23 \\
\hline tool punctated rows & 2 & 14 & 16 \\
\hline Totals & 15 & 123 & 138 \\
\hline
\end{tabular}

*on a strap handle

The incised sherds from the M. S. Roberts site have primarily straight line and/or geometric decorative elements (see Table 2), and are from Maydelle Incised vessels. The most frequent incised decorative elements other than parallel incised lines have diagonal opposed (Figure 7c), cross-hatched, diagonal, and horizontal 
and diagonal lines. One sherd has hatched zones (Figure 7e), and only one sherd (1.8 percent of the incised sherds) has curvilinear incised decorative elements. The most distinctive incised ceramics from the M. S. Roberts site are the sherds that have Poynor Engraved style scrolls and hatched triangle decorative elements that have been executed with incised lines rather than engraved lines (Figure 7a-b, d); these comprise 7.7 percent of the incised sherds in the assemblage.

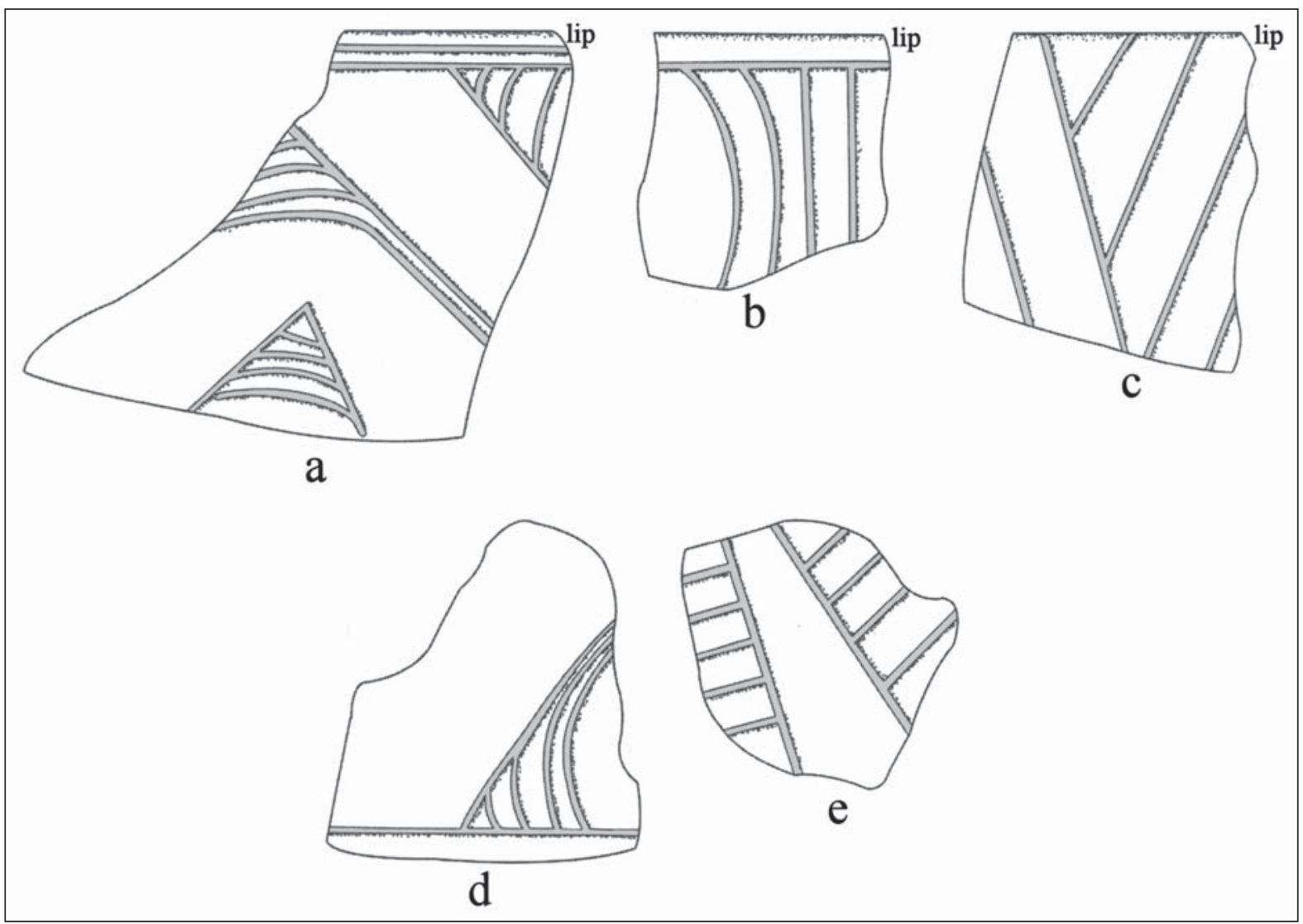

Figure 7. Selected incised decorative elements on sherds from the M. S. Roberts site: a-c, rim sherds; d-e, body sherds.

Three sherds ( 2.2 percent of the utility ware sherd assemblage), including a strap handle, have appliqued decorative elements. These include parallel fillets on the strap handle, a body sherd with curvilinear appliqued ridges, and another body sherd with a straight appliqued fillet and an adjacent appliqued node (Figure 8a). These sherds are probably from La Rue Neck Banded jars (see Suhm and Jelks 1962:93).

The sherds from vessels with brushing marks include one rim with horizontal brushing marks and body sherds with diagonal, opposed, overlapping, and parallel (probably oriented vertically) brushing marks on the vessel body. These are from Bullard Brushed jars (see Suhm and Jelks 1962:21). The few brushed-incised and brushed-punctated sherds are likely also from Maydelle Incised vessels with incised lines or punctations made through the brushing marks. The proportion of utility ware sherds with brushing marks (24.6 percent) in the M. S. Roberts assemblage is consistent with mid-14th to mid-15th century ancestral Caddo occupations in the upper Neches River basin (see Anderson et al. 1974; Perttula 2011). Only after ca. A.D. 1400 do brushed sherds dominate Late Caddo period Frankston phase ceramic assemblages (Perttula 2011:162).

Several of the incised-punctated rim and body sherds ( $\mathrm{n}=10,7.2$ percent of the utility wares) are from Maydelle Incised vessels (see Figure 8b-c, e) with either sets of diagonal incised lines forming incised tri- 


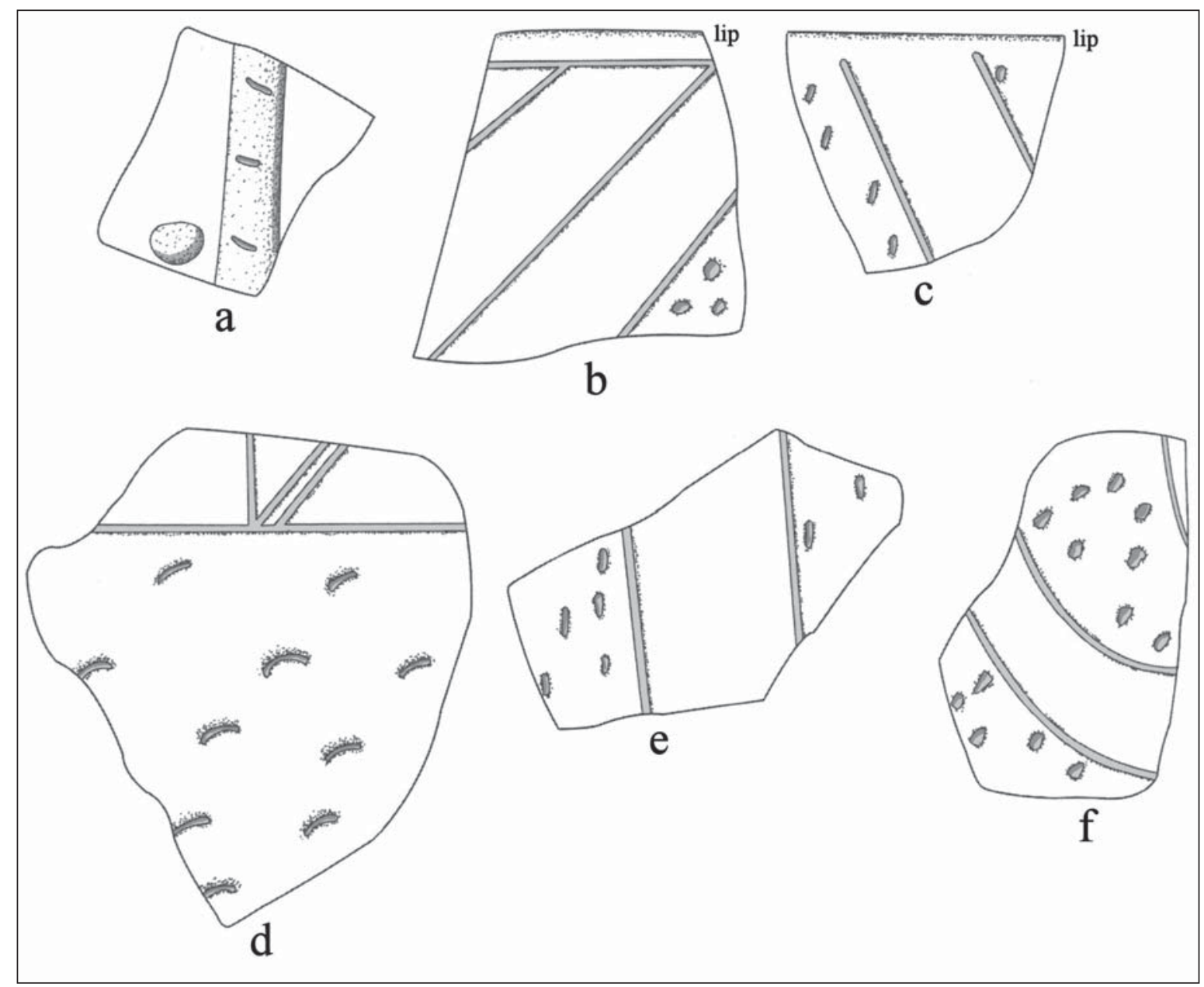

Figure 8. Selected appliqued and incised-punctated elements on sherds from the M. S. Roberts site: a, appliqued; b-f, incised-punctated.

angles filled with punctations or diagonal incised panels filled with punctations. One lower rim-body sherd from a jar has an incised motif with horizontal, vertical, and sets of diagonal incised lines on the rim and rows of fingernail punctations on the vessel body (see Figure 8d). One interesting incised-punctated sherd from a vessel of undetermined type from the site has curvilinear incised zones filled with tool punctations (see Figure 8f).

The punctated sherds are from both fingernail and tool punctated vessels. These vessels are simply decorated with rows of punctations on the upper part (rim and likely upper body) of utility ware vessels. Punctated utility wares in upper Neches River basin sites have only the most basic decorative elements (Suhm and Jelks 1962:Plate 79a-b).

The fine ware sherds are from both engraved ( $n=21,75$ percent of the fine wares) and red-slipped $(n=7$, 25 percent) vessels (Table 4). The majority of the engraved sherds are from upper Neches River Poynor Engraved vessels (Figure 9a-g), including var. Blackburn (Figure 9f-g), var. Cook (Figure 9e), and var. unspecified with a slanting scroll and curvilinear hatched triangle attachments (Figure 9d). Others have diagonal, horizontal, and vertical hatched zones (Figure 9a-c). Both var. Blackburn and var. Cook vessels are most common in ca. A.D. 1400-1560 Frankston phase sites in the upper Neches River basin (Perttula 2011:Table 6-37). 
Table 4. Decorative elements on fine ware sherds from the M. S. Roberts site.

\begin{tabular}{|c|c|c|c|}
\hline $\begin{array}{l}\text { Decorative method/ } \\
\text { Decorative element }\end{array}$ & Rim & Body & $\mathrm{N}$ \\
\hline \multicolumn{4}{|l|}{ Engraved } \\
\hline cross-hatched filled triangle elements & - & 1 & 1 \\
\hline curvilinear lines & - & 2 & 2 \\
\hline curvilinear lines, closely-spaced & - & 2 & 2 \\
\hline diagonal lines and horizontal hatched zone & 1 & - & 1 \\
\hline diagonal opposed lines & - & 1 & 1 \\
\hline diagonal scroll and sets of curvilinear lines & 1 & - & 1 \\
\hline horizontal line & - & 1 & 1 \\
\hline horizontal line and set of curvilinear lines & - & 1 & 1 \\
\hline horizontal and curvilinear lines & 1 & 1 & 2 \\
\hline horizontal line and diagonal hatched zone & 1 & - & 1 \\
\hline horizontal-diagonal-vertical-and curvilinear lines & - & 1 & 1 \\
\hline $\begin{array}{l}\text { horizontal and vertical lines and set of curvilinear } \\
\text { lines }\end{array}$ & - & 1 & 1 \\
\hline parallel lines & - & 3 & 3 \\
\hline straight line & - & 2 & 2 \\
\hline $\begin{array}{l}\text { vertical hatched zones and horizontal hatched } \\
\text { zone }\end{array}$ & 1 & - & 1 \\
\hline \multicolumn{4}{|l|}{ Slipped } \\
\hline ext. red-slipped & - & 2 & 2 \\
\hline int./ext. red-slipped & - & 5 & 5 \\
\hline Totals & 5 & 23 & 28 \\
\hline
\end{tabular}

Only one sherd (4.8 percent of the engraved sherds) from an engraved carinated bowl in the fine ware assemblage has a red ochre-rich pigment rubbed in the engraved design (see Figure 9c). The one engraved bottle sherd (see Figure 9h) is from a Poynor Engraved cylindrical-shaped vessel. It has sets of diagonal lines that may be part of a large triangle element, as well as another set of closely-spaced curvilinear engraved lines divided from other sets of engraved elements by single vertical or horizontal engraved lines (see Suhm and Jelks 1962:Plate 63a, e-f).

The proportion of red-slipped sherds - from both bowls, carinated bowls, and bottles - in the M. S. Roberts site fine wares is notable, as red-slipped sherds are not generally common at all in upper Neches River basin sites, or indeed in the Neches and Angelina river basins. Red-slipped fine wares (bowls, carinated bowls, and an occasional bottle) are a common part of ancestral Caddo ceramic assemblages in several parts of East Texas, most notably in sites in the middle Red River, the Big Cypress Creek basin, the upper Sulphur and Sabine River basin, and the middle Sabine River basin (Perttula 2015:Figure 3).

\section{Ceramic Pipe Sherd}

The single ceramic pipe sherd is from a bone-tempered pipe with a thick ( $14.2 \mathrm{~mm}$ in diameter) long stem, possibly an L-shaped elbow pipe (Perttula 2011:215 and Figure 6-23); its stem hole opening is 6.0 $\mathrm{mm}$. This form of elbow pipe is the earliest elbow pipe style in the upper Neches River basin and has been found in ca. A.D. 1320 to ca. A.D. 1480 Middle Caddo period to Frankston phase components in the region (see Perttula et al. 2012:15). 


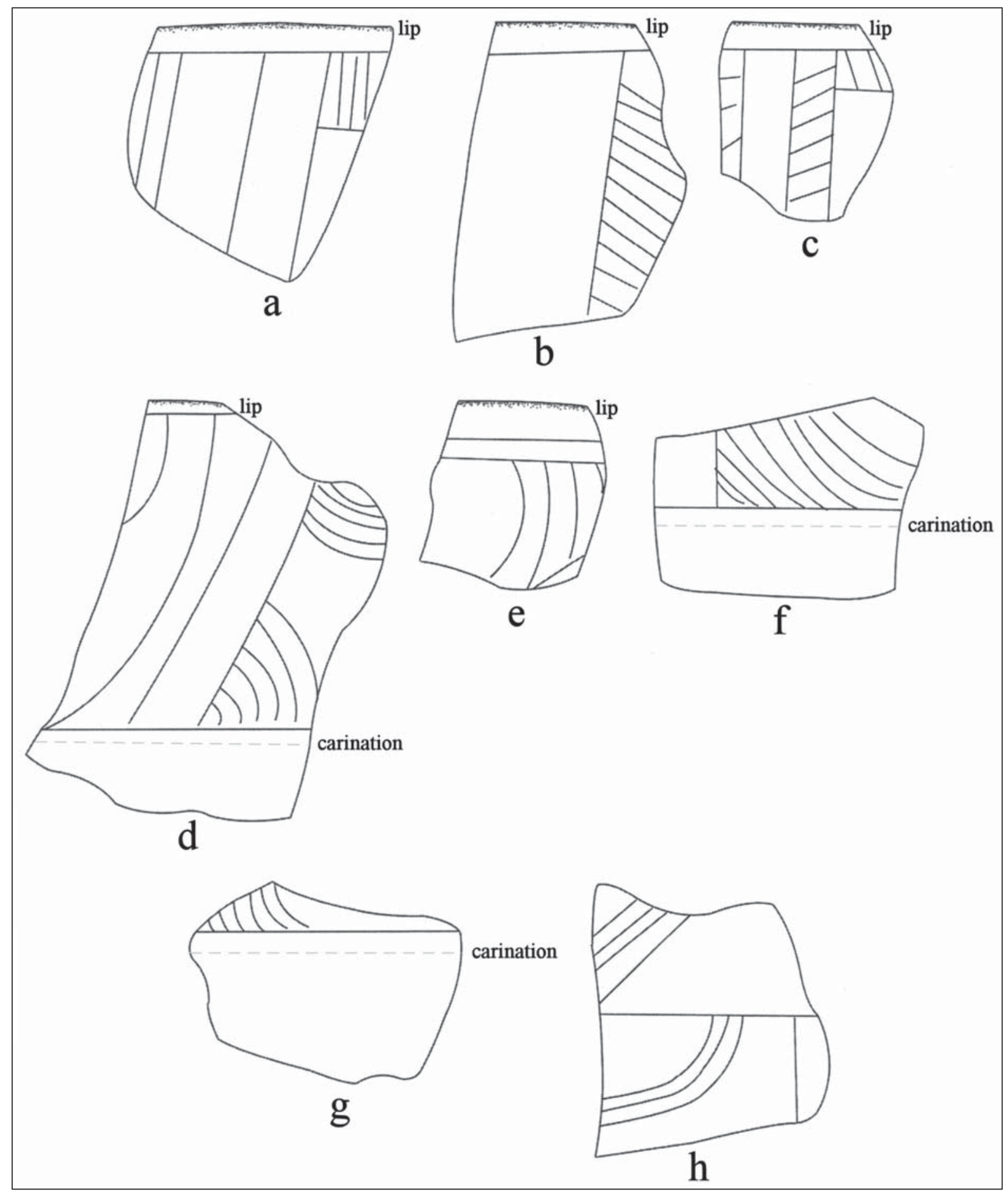

Figure 9. Selected decorative elements on engraved sherds from the M. S. Roberts site: a-e, rim sherd; f-g, lower rim sherds; $h$, bottle sherd. 


\section{SUMMARY AND CONCLUSIONS}

The A. S. Mann (41HE7) and M. S. Roberts (41HE8) sites are ancestral Caddo sites in the Caddo Creek valley in the upper Neches River basin in East Texas. Both sites were investigated by archaeologists from the University of Texas in the early 1930s, and there are collections of artifacts from both sites held at TARL. This includes eight ceramic vessels from a single Caddo burial from the A. S. Mann site and more than 400 sherds from ceramic vessels from mound and habitation contexts at the M. S. Roberts site.

The eight vessels from Burial AF-1 at the A. S. Mann site are funerary offerings in a Frankston phase burial feature; a second burial feature (Burial AF-2) was nearby, but no funerary offerings were recovered from this burial in the University of Texas investigations. As best as can be determined from the few ceramic vessels that are decorated, and comparisons to other burial features in the upper Neches River basin, this burial occurred between ca. A.D. 1480-1560 and was that of an adult individual. This site is just one of many family cemeteries dispersed across the basin and along Caddo Creek.

In the case of the M. S. Roberts site, it is one of only a few known Caddo earthen mound sites in the upper Neches River basin, the most prominent being the A. C. Saunders site (41AN19) on the Neches River to the east (Jackson 1936; Kleinschmidt 1982). The mound at the M. S. Roberts site began as a $24 \mathrm{~cm}$ thick deposit of yellow sand built on an alluvial terrace, and an important structure was built and used (for ritual and political purposes, perhaps) there, then eventually burned. At that point the yellow sand mound fill and the burned structure deposits were covered with a more massive mound fill more than $1.1 \mathrm{~m}$ in thickness. The mound was set within a settlement of unknown size and character, and the archaeological evidence of its use is marked by a small assemblage of plain and decorated ceramic vessel sherds and a possible L-shaped elbow pipe sherd in the TARL collections. These artifacts suggest that the Caddo construction of the mound and occupation of the settlement took place sometime in the first half of the 15th century A.D., and may have lasted until as late as ca. A.D. 1480, during the first part of the Frankston phase. Radiocarbon dates from the site are needed to refine the age of the Caddo occupation, and help establish when the mound feature was constructed, used, and then abandoned. At the present time, only a single Frankston phase mound is known: the A. C. Saunders site. The mound at the M. S. Roberts site may be the second mound site in a Late Caddo period Frankston phase community in the upper Neches River basin.

\section{ACKNOWLEDGMENTS}

I thank Mary Beth Tomka and Jonathan Jarvis for facilitating access to the records and collections from these two sites at the Texas Archeological Research Laboratory, The University of Texas at Austin. Lance Trask prepared the figures in this article.

\section{REFERENCES CITED}

Anderson, K. M., K. Gilmore, O. F. McCormick III, and E. P. Morenon

1974 Archaeological Investigations at Lake Palestine, Texas. Contributions in Anthropology No. 11. Department of Anthropology, Southern Methodist University, Dallas.

Jackson, A. T.

1936 A Perpetual Fire Site. Bulletin of the Texas Archeological and Paleontological Society 8:134-174.

Kleinschmidt, U. K. W.

1982 Review and Analysis of the A. C. Saunders Site, 41AN19, Anderson County, Texas. Master's thesis, Department of Anthropology, The University of Texas at Austin.

Pearce, J. E. and A. T. Jackson

1931 M. S. Roberts Farm, Henderson County, Texas Oct. 8 to Oct. 11, 1931. MS on file, Texas Archeological Research Laboratory, The University of Texas at Austin. 
Perttula, T. K.

2011 The Ceramic Artifacts from the Lang Pasture Site (41AN38) and the Place of the Site within an Upper Neches River Basin Caddo Ceramic Tradition. In Archeological Investigations at the Lang Pasture Site (41AN38) in the Upper Neches River Basin of East Texas, assembled and edited by T. K. Perttula, D. B. Kelley, and R. A. Ricklis, pp. 145-320. Archeological Studies Program Report No. 129, Texas Department of Transportation, Environmental Affairs Division, Austin.

2015 East Texas Caddo Ceramic Sherd Database. Journal of Northeast Texas Archaeology 51:1-46.

Perttula, T. K., D. B. Kelley, and R. A. Ricklis (assemblers and editors)

2011 Archeological Investigations at the Lang Pasture Site (41AN38) in the Upper Neches River Basin of East Texas. Report No. 129. Texas Department of Transportation, Archeological Studies Program, Environmental Affairs Division, Austin.

Perttula, T. K., M. Walters, and B. Nelson

2012 Archeological Investigations at the Pace McDonald Site (41AN51): A Middle Caddo Mound Center in the Neches River Basin in East Texas. Special Publication No. 21. Friends of Northeast Texas Archaeology, Pittsburg and Austin.

Suhm, D. A. and E. B. Jelks (editors)

1962 Handbook of Texas Archeology: Type Descriptions. Special Publication No. 1, Texas Archeological Society, and Bulletin No. 4, Texas Memorial Museum, Austin. Reprinted in 2009, Gustav's Library, Davenport, Iowa.

Woolsey, A. M.

1935 Notes on Field Work Mann Place 4 Mi. West of Frankston Anderson County October 17, 1935. MS on file, Texas Archeological Research Laboratory, The University of Texas at Austin. 